JEP | Volume 3 | Nomor 2| November 2019

e-ISSN 2579-860X

p-ISSN 2614-1221

http://jep.ppj.unp.ac.id/index.php/jep

Doi: https://doi.org/10.24036/jep/vol3-iss1/392

\title{
Analisis Integrasi Keterampilan Abad Ke-21 Dalam Sajian Buku Teks Fisika SMA Kelas XII Semester 1
}

\author{
Erlina Yusliani, Hanana Laila Burhan, Nurul Zakiatin Nafsih \\ Program Studi Magister Pendidikan Fisika Pasca Sarjana Universitas Negeri Padang \\ erlinayusliani@gmail.com \\ lailaburhan@gmail.com \\ nafsihnurul@gmail.com
}

\begin{abstract}
The $21^{\text {st }}$ century education requires students to be able to think critically, collaboratively, communicate, be creative and innovate. The Indonesian government made efforts to address the demands of $21^{\text {st }}$ century education by developing a 2013 curriculum that contained $4 C$ skills. The learning process requires a textbook as a learning research. Learning textbooks circulating are not in accordance with 2013 curriculum criteria to improve $4 C$ skills. The purpose of this study is to find out the Physics of Learning Textbooks for Class XII High School Semester 1 able to facilitate the implementation of $4 C$ skills in the $21^{\text {st }}$ century. This research is a descriptive study with a qualitative approach. The population of the data in the study were all physics of learning textbooks for class XII High School Semester 1. The sample was taken by using purposive sampling technique. The sample in this study was 5 Physics of learning Textbooks for Class XII High School Semester 1. The data in the study were taken using a questionnaire instrument. Based on the research that has been done, it can be concluded that the average for each component of $4 C$ Skills, namely critical thinking skills (C1) obtained by 85, collaboration skills (C2) by 93.57, communication skills (C3) by 78.50 and creative thinking and innovation skills (C4) by 65.45.
\end{abstract}

Keywords : 21 st century skills, 4 C component, Physics textbook

This is an open access article distributed under the Creative Commons 4.0 Attribution License, which permits unrestricted use, distribution, and reproduction in any medium, provided the original work is properly cited. $\odot 2019$ by author and Universitas Negeri Padang.

\section{PENDAHULUAN}

Perkembangan abad ke 21 ditandai dengan adanya keseimbangan antara Ilmu Pengetahuan dan Teknologi (IPTEK). Abad ke21 menuntut Sumber Daya Manusia (SDM) yang mampu beradaptasi dan memanfaatkan kecanggihan teknologi yang berkembang. Teknologi dapat dimanfaatkan oleh manusia apabila memiliki kompetensi untuk meng operasikannya. Kompetensi dapat meningkat dengan cara menyesuaikan perkembangan tekno logi, dan mengadaptasikan diri pada per ubahan zaman. Dengan demikian, adanya kom petensi dapat membentuk SDM yang kreatif, inovatif, kolaboratif, kompetitif, dan komparatif.

Pendidikan abad ke-21 menuntut keseim bangan teknologi dan pembelajaran. Pembelajaran yang diharapkan yaitu pembelajaran yang inovatif, kreatif, kolaboratif serta berpusat kepada peserta didik (Sugiyanti dkk, 2018). Pembelajaran pada abad ke-21 tidak hanya mengedepankan kemampuan kognitif saja tetapi juga mendahulukan keterampilan dari peserta didik (Sulistyaningrum dkk, 2019). Pendidikan abad ke-21 menuntut kompetensi pada peserta didikyang meliputi kompetensi pengetahuan, sikap dan keterampilan dapat meningkat (Usman dkk, 2017). Pada pendidikan abad ke21 tujuan pembelajaran dapat tercapai dengan peserta didik memiliki wawasan pengetahuan yang luas, dapat berpikir kritis, mampu berkerja sama, berkomunikasi yang baik, dapat mencipta kan dan memperbaharui suatu karya dan memi liki literasi (BSNP, 2010).

Salah satu upaya menyikapi tuntutan abad ke-21 pemerintah memberikan solusi dengan merancang mutu pendidikan di Indonesia dan melakukan evaluasi serta pengem bangan kurikulum (Nursurila dkk, 2018). Pengembang an kurikulum dilakukan untuk meningkatkan kualitas pendidikan, dengan merancang kurikulum baru yang menuntut peserta didik lebih aktif dalam proses pembelajaran. Kuri kulum baru yang menuntut peserta didik lebih aktif dalam proses pembelajaran yaitu Kuri kulum 2013. Kurikulum 2013 merupakan kurikulum yang berfokus pada pembentukan kompetensi, dan karakter peserta didik, dengan memadukan pengetahuan, keterampilan, dan 
sikap yang dapat didemonstrasikan peserta didik sebagai wujud pemahaman terhadap konsep yang dipelajarinya (Festiyed, 2015). Kurikulum 2013 bertujuan untuk meningkatkan dan menye imbangkan antara keterampilan dan pengetahu an peserta didik (Fadillah, 2014). Kurikulum 2013 meng acu pada tiga konsep pendidikan yaitu keteram pilan abad ke-21, pendekatan secara ilmiah, dan penilaian autentik (Hosnan, 2014). Ketiga konsep pendidikan tersebut sa ngat dipengaruhi oleh proses pembelajaran dan bahan ajar yang digunakan oleh pendidik dalam kegiatan pembelajaran.

Pembelajaran merupakan suatu kegiatan interaksi antara pendidik dan peserta didik dengan sumber belajar (Ananda \& Abdillah, 2018). Sumber belajar sebagai faktor penunjang bagi guru untuk mempermudah dalam menyam paikan pelajaran. Faktor penunjang berupa bahan ajar dapat berupa media dan sumber belajar yang digunkan agar tercapainya tujuan pembelajaran fisika yang diharapkan (Majid, 2018). Bahan ajar sebagai alat yang memiliki peran penting dalam proses pembelajaran pada semua mata pelajaran (Asrizal, dkk, 2018). Bahan ajar merupakan alat yang digunakan oleh pendidik untuk menyampaikan materi pelajaran kepada peserta didik, tujuannya membuat pembelajaran menjadi lebih menarik sehingga peserta didik lebih mudah memahami materi yang diajarkan oleh pendidik (Daryanto, 2014).

Bahan ajar disusun bertujuan untuk membuat pembelajaran lebih realistik, menarik, dan praktis (Festiyed, 2017). Bahan ajar yang sering digunakan dalam proses pembelajaran yaitu buku ajar. Bukuajar merupakan buku yang disusun untuk kepentingan proses kegiat an belajar (Asrizal, 2011; Prastowo, 2014). Buku ajar yang disajikan harus memiliki kualitas yang baik. Buku ajar yang baik harus memenuhi standar tertentu. Salah satu standar yang harus dipenuhi yaitu menerapkan keterampilan 4C. Keterampilan 4C merupakan keterampilan yang menyiapkan peserta didik agar mampu bersaing dan dapat menghadapi tantangan yang ada pada abad 21. Oleh karena itu, buku yang digunakan dalam proses pembelajaran harus mampu membe kali peserta didik untuk mengembang kan keterampilan yang sesuai dengan tantangan abad ke 21.

Kenyataannya kebanyakan buku ajar yang beredar belum sesuai dengan tuntutan kurikulum yang ada. Kebanyakan buku yang beredar tidak semuanya dapat memenuhi standar kurikulum yang dapat menumbuhkan keterampilan peserta didik agar mampu berpikir secara kritis, kreatif, inovatif, komunikatif dan kolaborasi. Hasilnya keterampilan yang diharap kan pada kurikulum 2013 tidak tercapai. Untuk itu diperlukan suatu solusi, yaitu buku ajar yang digunakan harus memuat komponen-komponen sesuai dengan tuntutan kurikulum yang ada. Buku ajar yang memuat komponen sesuai dengan tuntutan kurikulum 2013 dapat menumbuhkan keteram pilan yang diperlukan peserta didik di era modern ini. Keterampilan yang diperlukan peser ta didik agar sukses diera abad ke-21 adalah keterampilan 4C.

Penerapan keterampilan 4C diterapkan dalam pembelajaran kurikulum 2013 agar memberikan dampak yang luar biasa terhadap peserta didik agar mampu bersaing dalam menghadapi perkembangan zaman. Pembela jaran berbasis $4 \mathrm{C}$ ini dibutuhkan oleh peserta didik terutaman di Negara Indonesia yang bertujuan untuk melatih kemampuan dan bakat peserta didik untuk mengahadapi era revolusi baru yaitu revolusi 4.0 (Marlina \& Jayanti, 2019). Ke empat keterampilan tersebut yaitu Critical Thinking and Problem Solving (birpikir kritis dan pemecahan masalah), Communication (komunikasi), Collaboration (Kolaborasi) dan Creativity and Innovation (berpikir kreatif dan inovasi) (Susilo, 2015; Sani, 2014).

Birpikir kritis dan pemecahan masalah (C1)adalah suatu proses berpikir secara teliti serta tidak begitu saja menerima pendapat orang lain yaitu dengan cara bernalar, menganalisis serta dapat menyelesaikan permasalahan de ngan solusi alternatif sehingga dapat menambah pengetahuan peserta didik(Sunardi dkk., 2017; Sugiyanti dkk., 2018; Rahmi \& Suparman, 2019). Kemampuan berpikir kritis sangat di perlukan pada abad ke 21. Beberapa indikator yang ada dalam berpikir kritis yaitu: 1) memberikan penjelasan sederhana, 2) membangun keterampilan dasar peserta didik, 3) membuat kesimpulan, 4) membuat penjelasan lebih lanjut, dan 5) mengatur strategi dan taktik.

Kemampuan berpikir kritis biasanya diawali dengan kemampuan seseorang untuk menganalisis berbagai fenomena yang ada dise kitarnya dan mencari solusi dari permasalahan yang ada serta tidak mudah terpengaruh terhadap pendapat orang lain tanpa mengetahui kebenaran yang sebenarnya. Selain itu berpikir kritis merupakan suatu kognitif proses yang membantu pengaturan diri dan juga terkait untuk faktor motivasi seperti self-efficacy, hasil harapan, nilai tugas, dan orientasi tujuan. Ada- 
pun pengembangan definisi dari pemikiran kritis yaitu proses memeriksa secara internal dan mengeksplorasi masalah yang menjadi perhatian, dipicu oleh pengalaman tertentu, yang menciptakan dan mengklarifikasi makna dalam hal diri sendiri dan orang lain, serta yang menghasilkan perubahan perspektif dan hubungan konseptual. Di era reformasi keterampilan berpikir kritis,digunakan untuk mengatasi permasalahan yang bersifat radikal dan tidak masuk akal. Keterampilan lain yang dituntut pada abad ke 21 yaitu keterampilan kolaborasi (C2).

Keterampilan berkolaborasi yaitu kemam puan yang dimiliki oleh peserta didik untuk bekerja sama, menghormati dan bertanggung jawab atas apa yang dikerjakannya satu sama lain (Susanti \& Risnanosanti, 2019). Kolaborasi sangat memberikan maamfaat bagi peserta didik karena dengan berkolaborasi peserta didik memiliki potensi yang tinggi untuk memecah kan masalah ilmiah yang kompleks (Rahmi \& Suparman, 2019). Beberapa indikator dari kete rampilan berkolaborasi yaitu: 1) menunjukan kemampuan bekerja sama dalam kelompok secara efektif dan saling menghormati satu sama lain, 2) fleksibelitas secara pribadi, kemampuan saling membantu, berkompromi untuk mencapai tujuan bersama, dan 3) bekerja secara produktif serta bertanggung jawab. Keterampilan berkolaborasi dapat dijadikan sebagai salah satu kemapuan untuk membantu peserta didik bekerja sama dan bertanggung jawab untuk dirinya sendiri dan orang lain. Dengan cara ini membuat peserta didik senantiasa berguna bagi lingkungan sekitar.Selain keterampilan kolaborasi keterampil an 4C penting lainnya yaitu keterampilan untuk berkomunikasi (C3) peserta didik.

Komunikasi adalah suatu kegiatan un tuk mentrasfer suatu informasi dapat berupa tulisan maupun lisan dengan menyampaikan nya secara baik (Susanti \& Rosnanosanti, 2019). Keterampilan komukasi peserta didik memiliki beberapa indikator diantaranya yaitu: 1) mema hami, mengolah, dan menciptakan komunikasi yang efektif, 2) menyampaikan pikiran dan ideide secara efektif dalam berbagai bentuk dan isi baik secara lisan maupun tulisan, 3 ) mendengar kan secara efektif untuk memahami makna termasuk pengetahuan, sikap, nilai dan minat, 4) menggunakan komukasi untuk berbagai tujuan (member informasi, instruksi, memotivasi dan persuasi), 5) memamfaatkan media komunikasi dan teknologi dan tahu bagaimana menilai efektifitas dan dampaknya, 6) berkomuikasi secara efektif dalam berbagai lingkungan (Marlina, 2019). Selain keterampilan berkomuni kasi pada abad ke 21 juga menuntut peserta didik untuk memiliki keterampilan berpikir kreatif dan Inovasi (C4).

Keterampilan berpikir kreatif dan inovasi merupakan suatu kemampuan yang berguna untuk menghasilkan sesuatu yang baru. Kreativitas ini perlu untuk diasah tujuannya yaitu agar peserta didik mampu mengembangkan serta menyampaikan gagasan baru yang dimilikinya dan disampaikan kepada orang lain secara terbuka dan responsif. Keterampilan berpikir kreatif dan inovasi dapat memberikan peluang kepada peserta didik untuk bersaing dan memenuhi segala kehidupannya di era modern ini (Sugi yanti, 2018; Marlina, 2019).

Keterampilan berpikir kreatif dan inovasi menuntut peserta didik untuk bisa lebih kreatif dalam menemukakan suatu ide yang dimilikinya serta dapat diaplikasikannya dalam kehidupan. Semua keterampilan 4C sangat berguna bagi peserta didik. Dengan demikian, keterampilan 4C merupakan keterampilan yang dapat membantu peserta didik untuk berkomunikasi dan mengikuti kehidupan sesuai dengan perkembangan zaman.

Penelitian relevan yang terkait dengan penelitian ini yaitu Rahmi \& Suparman, Sulistyaningrum dkk, Susanti \& Risnanosanti dan Dewi. Ada beberapa perbedaan penelitian ini dengan penelitian relevan. Pertama, Bahan ajar yang dianalisis pada penelitian relevan yaitu modul. Kedua, keterampilan abad ke 21 dinilai menggunakan model pembelajaran berbasis proyek. Ketiga, keterampilan abad ke 21 yang dinilai bukan keterampilan 4C tetapi hanya keterampilan berpikir keatif dan kritis.

Tujuan penelitian ini yaitu untuk meng analisis keterampilan abad ke-21 pada buku ajar Fisika kelas XII SMA Semester 1, keterampilan yang dilihat pada buku yaitu keterampilan 4C. Buku ajar yang beredar diharapkan dapat digunakan untuk meningkatkan keterampilan peserta didik dan sesuai dengan tuntutan yang diharapkan pada pendidikan abad ke-21 ini.

\section{METODE PENELITIAN}

Jenis dari penelitian yang dilakukan merupakan penelitian deskriptif dengan pendekatan kualitatif. Penelitian deskriptif yaitu penelitian yang mendeskripsikan fenomena yang bersifat nyata ataupun yang direkayasa. 
Pada penelitian ini yang dilakukan adalah mendeskripsikan komponen keterampilan 4C pada buku ajar fisika kelas XII semester 1. Populasi dalam penelitian ini adalah seluruh buku ajar fisika SMA kelas XII semester 1. Teknik pengambilan sampel yang digunakan adalah nonprobability sampling dengan jenis purposive sampling, dimana teknik ini digunakan dengan tujuan dan pertimbangan tertentu. Sampel yang diambil pada penelitian ini yaitu buku ajar fisika SMA kelas XII semester 1 sebanyak 5 buah buku. Kelima buku ini merupakan buku edaran yang disebarkan pemerintah berbasis kurikulum 2013.

Prosedur pada penelitian ini terdiri dari tiga tahapan, diantaranya tahapan persiapan, pelaksanaan, dan penyelesaian. Tahap persiapan yaitu merancang penelitian, menentukan subjek dan objek penelitian atau buku yang akan digunakan, mempersipakan instrumen penelitian (Arikunto, 2014). Pada penelitian ini untuk tahapan persiapan adalah memperoleh informasi mengenai buku ajar fisika SMA kelas XII semester 1 seperti yang melakukan studi penda huluan, lalu merancang, menentukan subjek dan objek penelitian serta mempersiapkan instru men penelitian.

Tahap pelaksanaan yaitu melakukan pengumpulan data sesuai dengan kebutuhan. Tahapan pelaksanaan pada penelitian ini adalah mengumpulkan data dengan cara menganalisis keterkaitan komponen keterampilan 4C sesuai dengan kriteria kurikulum 2013 pada kelima buku ajar fisika kelas XII semester 1.

Tahap terakhir yaitu tahap penyelesaian. Tahapan ini memuat kegiatan mengolah data hasil penelitian, menarik kesimpulan, dan melaporkan hasil penelitian. Tahap terakhir didalam penelitian ini data yang diperoleh dari menganalisis kelima buku kemudian diolah, ditarik kesimpulannya, serta dibuat laporan hasil penelitian dari data yang telah diolah.

Instrumen penelitian yang digunakan pada penelitian ini sebagai alat yang digunakan untuk mengukur sesuatu yang diamati berupa angket. Angket ini merupakan lembar analisis berbentuk pernyataan yang terdiri dari empat komponen sesuai dengan keterkaitan pada keterampilan 4C. Angket memiliki butir penilaian dengan rentang 1-4 yang terdapat pada masing-masing komponen, yaitu berpikir kritis dan pemecahan masalah, komunikasi, Kolaborasi dan berpikir kreatif dan inovasi pada materi pokok SMA Kelas XII Semester 1.
Teknik pengumpulan data yang diguna kan yaitu teknik analisis data. Pada penelitian ini analisis data yang digunakan yaitu analisis isi dengan menganalisis isi pada buku yang telah tertulis. Pada penelitian ini, data diolah dengan cara analisis statistik deskriptif dengan melakukan perhitungan menggunakan rumus sebagai berikut:

$$
\text { Nilai }=\frac{\text { Skor }}{\text { Skor maksimum }} \times 100
$$

Rumus lain yang digunakan untuk meng hitung rata-rata skor komponen keterampilan 4C pada buku ajar yang dianalisis adalah :

$$
\bar{X}=\frac{\sum X i}{n}
$$

Keterangan :

$$
\begin{aligned}
\bar{X} & =\text { Rata-rata skor } \\
\sum_{\mathrm{n}} X i & =\text { Jumlah nilai } \\
& =\text { Jumlah indikator komponen }
\end{aligned}
$$

Kriteria untuk menganalisis isi buku ajar fisika SMA kelas XII semester 1 yang berkaitan dengan komponen keterampilan 4C mengguna kan skala likert dengan kategori pada tabel 1 .

Tabel 1.Kategori Analisis Buku Ajar

\begin{tabular}{|c|c|}
\hline Tingkat Pencapaian & Kategori \\
\hline $81-100$ & Sangat Baik \\
\hline $61-80$ & Baik \\
\hline $41-60$ & Cukup Baik \\
\hline $21-40$ & Kurang Baik \\
\hline $0-20$ & Buruk \\
\hline
\end{tabular}

(Riduwan, 2010).

\section{HASIL DAN PEMBAHASAN}

\section{Hasil Penelitian}

Penelitian dengan judul Analisis Buku Ajar Fisika SMA Kelas XII Semester 1 Terkait Komponen 4C pada Keterampilan Abad ke 21 yang dilakukan terhadap lima Produk / Buku ajar yang digunakan sebagai buku pedoman peserta didik di sekolah. Buku ajar fisika yang diterapkan pada setiap institusi / sekolah di level Sekolah Menengah Atas/ sederajat (SMA) peserta didik di kelas XII menggunakan kurikulum 2013.

Kemampuan keterampilan dalam 4C pe serta didik diharapkan dapat mengembangkan kemampuan yang ada dalam dirinya serta dapat mengembangkan kompetensi yang peseta didik miliki sesuai dengan tuntutan abad ke-21. Kelima buku ajar tersebut dianalisis serta 
dilakukan perhitungan sehingga diperoleh ratarata berdasarkan komponen 4C. Komponen pertama yang dianalisis pada buku ajar adalah keterampilan birpikir kritis dan pemecahan masalah. Berikut ini disajikan hasil analisis keterampilan berpikir kritis dan pemecahan masalah dari kelima buku ajar fisika yang dipakai oleh beberapa sekolah :

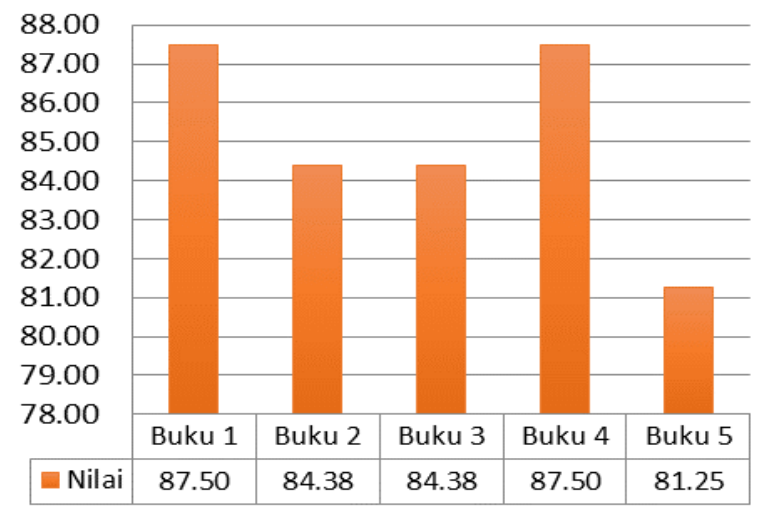

Gambar 1. Komponen Berpikir Kritis dan Pemecahan Masalah

Berdasarkan Gambar 1 dapat diungkap kan bahwa buku ajar yang mendapatkan persentase rata-rata tertinggi yaitu buku 1 dan buku 4 dengan perolehan persentase sebesar $87,50 \%$. Persentase $87.50 \%$ berada pada kategori sangat kuat. Dari data ini dapat dinyatakan bahwa isi dari buku 1 dan buku 4 memuat keterampilan berpikir kritis dan pemecahan masalah peserta didik yang sangat tinggi dan dapat digunakan dalam proses pembelajaran. Keterampilan berikutnya yang dianalisis pada kelima buku ajar tersebut adalah keterampilan berkolaborasi peserta didik. Hasil analisis dari keterampilan kolaborasi yang dimuat pada kelima buku ajar tersebut dapat dilihat pada Gambar 2 berikut ini:

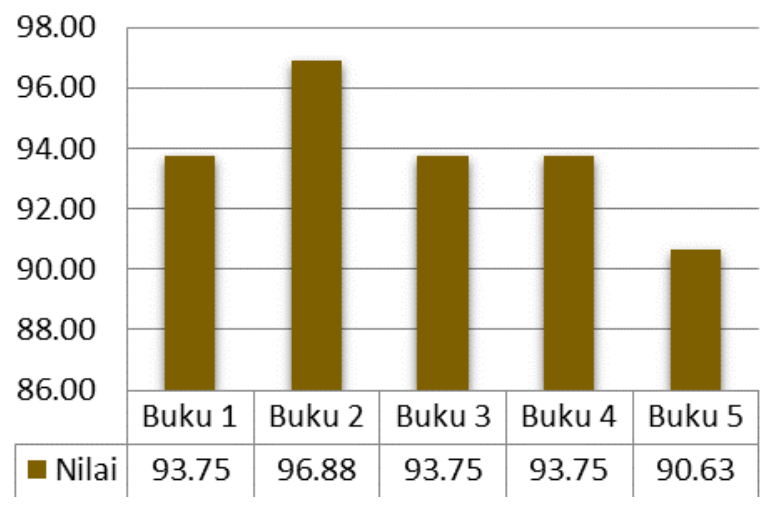

Gambar 2. Keterampilan Kolaborasi

Berdasarkan Gambar 2 tersebut dapat dijelaskan bahwa buku ajar yang memiliki persentase terbesar adalah buku 2 dengan parsen- tase $96.88 \%$. Nilai parsentase $96.88 \%$ termasuk kedalam kategori sangat tinggi. Jadi dapat disim pulkan bahwa buku 1 memuat keterampilan kolaborasi yang sangat tinggi sesuai dengan tuntutan abad ke 21 yang diharapkan dan layak digunakan pada pembelajaran Kurikulum 2013. Selanjutnya berikut ini disajikan hasil analisis dari kelima buku tentang keterampilan komunikasi yang termuat didalamnya.

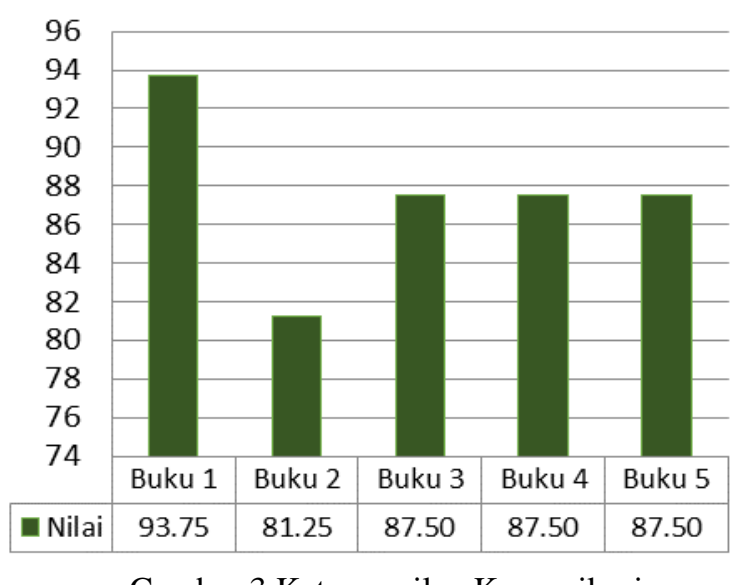

Gambar 3 Keterampilan Komunikasi

Hasil analisis pada Gambar 3 dapat dilihat bahwa buku ajar yang mendapatkan persentase tertinggi yaitu buku 1 dengan perolehan persen tase sebesar 93,75\%. Kesimpulannya yaitu bahwa buku 1 memuat keterampilan komunikasi yang lebih tinggi dari buku yang lain. Dengan demikian buku 1 sudah memuat keterampilan komukasi sesuai dengan tuntutan Kurikulum 2013 dan Abad ke-21. Analisis keterampilan berpikir kreatif dan inovasi untuk kelima buku dapat dilihat pada Gambar 4 berikut ini:

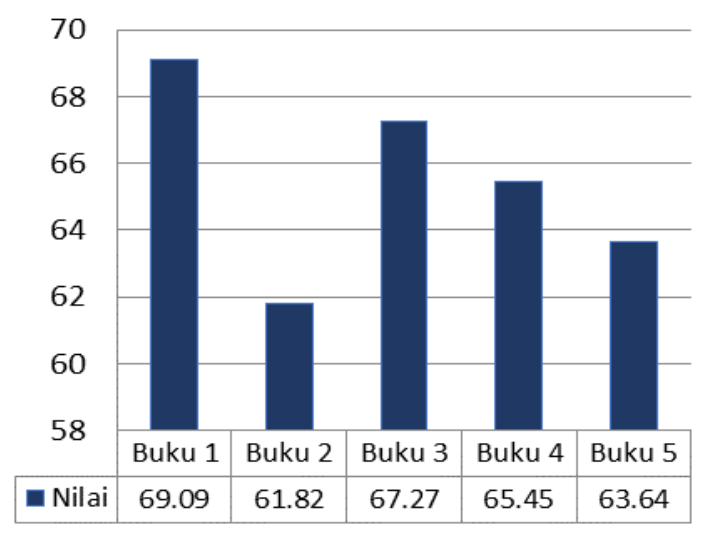

Gambar 4. Keterampilan Berpikir Kreatif dan Inovasi

Berdasarkan Gambar 4 dapat dijelaskan bahwa buku ajar yang mendapatkan persentase tertinggi terlihat pada buku 1 dengan perolehan persentase sebesar 69,09\%. Dari hasil ini dapat dinyatakan bahwa buku 1 memuat keterampilan 
berpikir kreatif dan inovasi yang tinggi dari 4 buku yang lain serta sesuai dengan tuntutan kurikulum 2013. Nilai rata-rata dari komponen keterampilan $4 \mathrm{C}$ dari kelima buku ajar yang dianalisis ditampilkan pada Gambar 5:

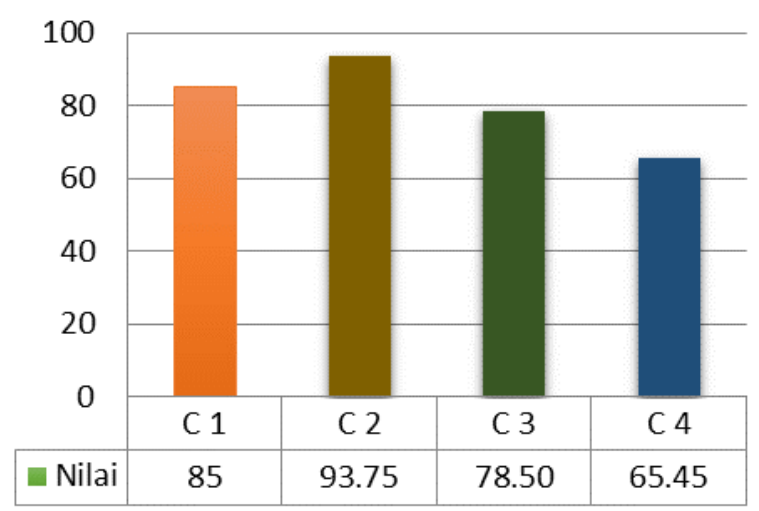

Gambar 5 Perbandingan Hasil Analisis keterampilan $4 \mathrm{C}$ yang dimuat pada Buku Ajar Fisika Kelas XII Semester 1 4C

Gambar 5 merupakan hasil analisis kom ponen keterampilan 4C dari kelima buku. Keterampilan tertinggi yang dimiliki oleh ke 5 buku tersebut setalah dianalisis yaitu keterampilan kolaborasi. Secara keseluruhan dapat disimpukan bahwa kelima buku tersebut sudah memuat keempat komponen sesuai dengan apa yang diharapkan pada abad ke 21. Keterampilan ter tinggi yang dimuat oleh kelima buku tersebut yaitu keterampilan kolaborasi, kedua keteram pilan berpikir kritis, ketiga keterampilan komunikasi dan terakhir yaitu keterampilan berpikir kreatif dan inovasi.

\section{Pembahasan}

Analisis Sajian Buku Ajar Fisika yang dikaitkan dengan komponen $4 \mathrm{C}$ pada keteram pilan abad ke 21 ini bertujuan untuk mengetahui keberadaan komponen keterampilan 4C pada buku ajar yang mencakup keterampilan berpikir kritis dan pemecahan masalah, komunikasi, kolaborasi dan berpikir kreatif dan inovasi. Keempat komponen tersebut merupakan kemampuan sesungguhnya yang ingin dituju de ngan kurikulum 2013.

Analisis pertama yang dilakukan pada penelitian ini yaitu memilih beberapa buku yang akan dianalisis. Buku yang dianalisis yaitu buku ajar Fisika kelas XII semester 1 yang digunakan oleh peserta didik dalam proses pembelajaran. Kebanyakan buku ajar yang dipakai oleh peserta didik dalam proses pembelajaran banyak yang tidak sesuai dengan tuntutan kurikulum 2013. Ketidaksesuaian dengan tuntutan kuri kulum berdampak pada tujuan pembelajaran yang diharapkan.

Pengumpulan data untuk melihat kompo nen keterampilan $4 \mathrm{C}$ pada buku teks menggu nakan angket yang dibuat berdasarkan indi kator-indikator yang sesuai dengan kajian teori. Selanjutnya dilakukan analisis kepada kelima buku tersebut. Keterampilan pertama yang dianalisis pada kelima buku tersebut adalah keterampilan berpikir kritis dan pemecahan masalah.Analisis buku tersebut disesuaikan dengan indikator-indikator berpikir kritis dan pemecahan masalah sehingga diperoleh hasil bahwa kelima buku teks telah memuat indikatorindikator berpikir kritis yang diharapkan dan buku yang memilliki keterampilan berpikir kritis yang tinggi yaitu buku yang pertama. Penerapan berpikir kritis diharapkan peserta didik mampu menganalisa dan memecahkan suatu masalah, karena itu peserta didik harus banyak membaca agar menambah ilmu pengeta huan (Sunardi dkk., 2017).

Keterampilan kolaborasi di dalam buku ajar harus saling berkesinambungan antara materi yang dipelajari dengan kondisi pada kehidupan sehari. Keterampilan kolaborasi diharapkan peserta didik dapat menerapkan keinginan untuk bekerja sama dengan orang lain, karena sukses tidak bisa berjalan dengan sendirinya perlu bekerja sama dengan orang lain. Melalui buku ajar diharapkan peserta didik bisa menerapkan keterampilan komunikasi yang artinya bagaimana peserta didik mempunyai kemampuan untuk berkomunikasi dengan orang lain, baik memperhatikan empati dan mende ngarkan (Susanti \& Risnanosanti, 2019).

Keterampilan berpikir kreatif dapat ber peran sebagai penghubung antara peserta didik dengan lingkungannya. Penerapan berpikir kreatif di dalam buku ajar bertujuan bagaimana peserta didik melakukan suatu hal dengan cara yang berbeda dari cara yang sebelumnya bukan dengan cara yang seperti itu saja agar dapat bersaing pada kondisi dunia yang berkembang pada saat ini (Sugiyanti, 2018; Marlina, 2019).

\section{KESIMPULAN}

Berdasarkan penelitian yang telah dilakukan, maka dapat disimpulkan bahwa Keterampil an tertinggi yang dimiliki oleh ke 5 bu$\mathrm{ku}$ tersebut yaitu keterampilan kolaborasi dengan persentase rata-rata sebesar 93.57, keterampilan berpikir kritis diperoleh rata-rata 
sebesar 85, keterampilan komunikasi yaitu sebesar 78.50 dan keterampilan berpikir kreatif dan inovasi diperoleh 65.45. Dengan demikian dapat disimpukan bahwa kelima buku tersebut sudah memuat keempat komponen sesuai dengan apa yang diharapkan pada Abad ke 21 dengan keterampilan tertinggi yang dimiliki oleh kelima buku teks tersebut adalah keterampilan kolaborasi dan keterampilan yang rendah yaitu keterampilan berpikir kreatif serta inovasi.

\section{DAFTAR PUSTAKA}

Abdul, M. (2008). Perencanaan Pembelajaran, Mengembangkan Standar Kompetensi Guru. Jakarta:Rineka Cipta

Ananda, R., \& Abdillah. (2018). Pembelajaran Terpadu. Medan: Lembaga Peduli Pengembangan Pendidikan Indonesia (LPPPI).

Arikunto, S. (2014). Prosedur Penelitian Suatu Pendekatan Praktik. Jakarta : Rineka Cipta.

Asrizal., Handayani,P., \& Desnida, P. (2011). Pengembangan Buku Ajar Fisika Berbasis Multimedia Interaktif untuk Pembelajaran Siswa R-SMA-BI Kelas XI Semester 1.Jurnal Prosiing Seminar Nasional HFI Cabang Sumatera Barat Padang, ISBN978-602-19069-0-3.

Asrizal, Festiyed, \& Sumarmin, R. (2017). Analisis Kebutuhan Perkembangan Bahan Ajar IPA Terpadu Bermuatan Literasi Era Digital Untuk Pembelajaran Siswa SMP Kelas VIII. Jurnal Eksakta Pendidikan (JEP) Volume 1 Nomor 1 Mei 2017 eISSN 2579-860X.

Asrizal, A., Amran, A., Ananda,A., Festiyed,F ., Sumarmin, R. (2018). The Development of Integrated Science Instructional Materials to Improve Students Digital Literacy in Scientific Approach. Jurnal Pendidikan Indonesia, Doi : 10. 15294/JPII. V7i4. 13613.

Badan Standar Nasional Pendidikan (BSNP). (2010). Paradigma Pendidikan Nasional Abad XXI Retrieved from laporan BSNP.

Daranto. (2014). Pembelajaran Tematik, Terpadu, Terintegrasi Kurikulum (2013). Yoyakarta : Gava Media.
Dewi, F. (2015). Proyek Buku Digital: Upaya Peningkatan Keterampilan Abad 21 Calon Guru Sekolah Dasar Melalui Model Pembelajaran Berbasis Proyek. Metode Didaktik. Vol 9, No.2, hlm. 1-15

Fadillah. (2014). Implementasi Kurikulum (2013). Dalam Pembelajaran SD/MI, SMP/MTs, \& SMA/MA. Yogyakarata : Ar-Ruzz Media.

Festiyed, (2015). Studi Pendahuluan Pengimplementasian Kurikulum 2013 Dalam Mengintegrasikan Pendekatan Saintifik Melalui Model Inkuiri dan Authentic Assessment Dalam Pembelajaran IPA di Kota Padang. Semirata 6-9 Mei 2015, Universitas Tanjung Pura, Pontianak.

Hosnan. (2014). Pendekatan Saintifik dan Kontekstual dalam Pembelajaran Abad 21. Bogor: Ghalia Indonesia.

Marlina, W., \& Jayanti, D. (2019). 4C dalam Pembelajaran Matematika untuk Menghadapi Revolusi 4.0. Prosiding Sendika. Vol 5, No 1, hlm 392-396.

Nururila, N., Darvina, Y., Hidayati., \& Masril. (2018). Pembuatan LKS Berbasis Virtual Laboratory Melalui ICT pada Materi Gelombang Optik, dan Pemanasan Global Kelas XI SMA. Jurnal Pillar of Physics Education, Vol 11. No. 3. 2018.193-200.

Prastowo, Andi. (2014). Pengembangan Bahan Jar Tematik Tinjauan Teoritis dan Praktik. Jakarta : Kencana.

Rahmi, A., \& Suparman, S. (2019). Analisis Kebutuhan Modul Dengan Pendekatan CTL untuk Meningkakan Motivasi Belajar dan Keterampilan 4 C pada Peserta Didik. Prosiding Sendika. Vol. 5. No. 1 hlm. 121-126.

Riduan, (2010). Belajar Mudah Penelitian untuk Guru Karyawan dan Penulis. Bandung : Alfabeta.

Sani, R. A. (2016). Penilaian Autentik. Jakarta : Bumi Aksara.

Sugiyanti, L., Alif, A., \& Mursalin, M. (2018). Pembelajaran Pada Abad Ke 21 di SD. Prosiding Seminar dan Diskusi Nasional Pendidikan Dasar.hlm. 439-444.

Sulistyaningrum, H., Winata, A., \& Cacik, S. (2019). Analisis Kemampuan Awal 21 
Century Skills Mahasiswa Calon Guru SD. Jurnal Pendidikan Dasar Nusantara. Vol. 5. No. 1, hlm 142-158.

Sunardi., Kurinanti, D., Sugiarti, T., Yudianto, E., \& Nurmaharani, R. (2017). Pengenbangan Indikator 4C's yang Selaras dengan Kurikulum 2013 pada Pelajaran Matematika SMA/MA Kelas X Semester1. AdMathEdu. Vol.7, No. 2, hlm.197-210.

Susanti, D., \& Risnanosanti. (2018). Pegembangan buku ajar untuk Menumbuh Kembangkan Kemampuan 4C (Critical, Creatif, Colabirative, Communivcative) Melalui PBL pada Pembelajaran Biologi di SMP 5 Seluma. Prosiding Seminar Nasional Sains dan Enterpreneurship VI Tahun 2019. Hlm, 1-9.

Usman, E, A., Asrizal., Kamus, Z (2017). Pengembangan LKS IPA Terpadu Mengintegrasikan Literasi Saintifik pada Materi Gerak Dalam Kehidupan untuk Siswa Kelas VIII SMP . Pillar of Physics Education, Vol. 9 April 2017, hlm 25-23.

Wijaya, E. Y., Sudjimat,D. A., \& Nyoto.,A (2016). Transformasi Pendidikan Abad 21 sebagai Tuntunan Pengembanagan Sumber Daya Manusia di Era Globalisasi. Prosiding Seminar Nasional Pendidikan Matematika. Vol. 1, hlm 263278. 